\title{
BREEDING FOR BETTER GROWTH OF Calliandra calothyrsus Meissn., A FAST GROWING LEGUME FOR WOOD-ENERGY
}

(Pemuliaan Perbaikan Pertumbuhan Calliandra calothyrsus Meissn., Tanaman Cepat Tumbuh Jenis Legum Untuk Kayu Energi)

\section{* Rina Laksmi Hendrati and/ dan Siti Husna Nurrohmah}

Centre for Forest Biotechnology and Tree Improvement Research and Development, Indonesian Ministry of Environment and Forestry, Jl. Palagan T. Pelajar km 15, Telp: +62-0270-896080, 895954. Fax. +62-0270-896080Purwobinangun, Pakem, Sleman, Yogyakarta 55582, Indonesia e-mail : rina.1.hendrati@biotifor.or.id

Paper submitted: July $6^{\text {th }}$ of 2018; Paper revised: September $19^{\text {th }}$ of 2018; Paper accepted: $21^{\text {st }}$ Nopember of 2018

\section{ABSTRAK}

Tanaman berkayu rotasi pendek untuk energi terbarukan yang dapat mengantisipasi penurunan energi fosil, telah menarik minat negara-negara tropis yang memiliki kadar hujan dan sinar matahari yang melimpah. Calliandra calothyrsus, sejenis pohon multifungsi yang cocok untuk kayu energi sangat potensial sebagai tanaman rotasi pendek. Tanaman pengikat nitrogen ini mampu menyediakan sumber energi dengan hanya menanam sekali namun bisa dipanen tahunan hingga 15-20 tahun dari trubusannya. Selain itu, tanaman ini menunjang penutupan vegetasi untuk mitigasi perubahan iklim. Jenis cepat tumbuh, bervolume dan berkualitas tinggi merupakan prasyarat sebagai energi biomasa dari kayu. Dalam rangka mengoptimalkan tujuan ini, pemuliaannya telah dilakukan pada tahun 2011 - 2014 untuk mendapatkan individu terbaik dalam hal volume dan kualitas. Dalam kajian ini perbaikan pertumbuhan dengan membandingkan anakan-anakan dari pohon unggul (5 famili) yang diseleksi tahun 2014 dari uji keturunannya di Wonogiri, Jawa Tengah, terhadap lima (5) famili dari yang tidak dimuliakan, dilakukan. Perbaikan karakter pertumbuhan telah ditunjukkan sangat nyata berbeda pada tanaman siap tanam di lapangan umur 4 bulan. Pemuliaan Calliandra telah terbukti meningkatkan jumlah daun, tinggi tanaman, diameter dan kualitas semai hingga 23,4 persen, 24,3 persen, 6,7 persen dan 20 persen secara berturutan. Materi yang lebih komplit telah ditanam sebagai uji perolehan genetik pada tahun 2016. Diharapkan kecenderungan yang serupa juga akan dapat diperoleh setelah penanaman di lapangan dilakukan.

Kata Kunci : Calliandra calothyrsus, kayu energi, pohon plus, pemuliaan, perolehan genetik

\section{ABSTRACK}

Short-rotation woody crops for renewable energy in anticipating decreasing fossil energy resources, has been a great interest for tropical countries where rain and sunshine are abundant. Calliandra calothyrsus, a multipurpose tree suitable for energy-wood is a very potential as short-rotation crop. This nitrogen-fixing species can be utilized as energy-wood by planting once but is able to secure annual harvest up to 15-20 years from its coppices. Beside that, this species supports earth vegetation cover for mitigating climate change. This fast growing, high volume and quality species fulfills requirement for energy needs as renewable wood biomass. In optimizing this role, its genetic improvement was undertaken during 2011 2014 to obtain the best energy-wood individuals in volume and quality. This study examined the growth-gain by comparing off spring of genetically improved trees ( 5 families) selected in 2014 from progeny test in Wonogiri, Central Java, to five (5) families from the unimproved ones. Significant differences on important growth characters have been obtained at the age of 4-month plants ready for field plantation. Calliandra's genetic improvement has proven to increase the number of leaves, height, diameter and seedling quality up to 23.4 percent, 24.3 percent, 6.7 percent and 20 percent consecutively. More complete materials have been established as realized genetic-gain trials in 2016. It is expected that similar trends will be realized in the fields.

Keywords: Calliandra calothyrsus, energy-wood, plus trees, genetic gain, improvement

\section{INTRODUCTION}

Development of short-rotation wood crops

for renewable energy which is expected to anticipate the running down of fossil energy resources, has been of great interest especially in tropical countries where its growth can be

*Author contributions: Rina Laksmi Hendrati is the main contributor of the work and this paper 
optimized due to abundance of rain and sunshine (Openshaw, 2010). Further, maximum growth can be encouraged by proper management of water supply, fertilizer, reduction of plant competitions, and pest and diseases problems. Nevertheless, the need of selective breeding that can produce genetically improved individuals meant for biomass and quality production is very vital (Zalesny, Zalesny, McMahon, Berguson \& Stanosz, 2009).

Species grown for sustainable shortrotation energy plantation is expected to provide wood biomass supply, great carbon storage, acceptable fossil fuel substitution, environment services and economic improvement for local communities (Dwiyedi \& Khanna, 2014; Murtala, Aliyu \& Babagana, 2012; Oliver, Nassar, Lippke \& McCarter 2014). Such targeted advantages can also be found in Calliandra calothyrsus. A series of breeding program for this species was initiated in 2010. Plus trees selection was carried out in 2014, covering 10 populations from throughout Indonesia. The main selection criteria were volume and quality firewood energy. Calliandra is a very fast growing legume species which is able to fix nitrogen and reach the growth up to $2 \mathrm{~m}$ just within 2-3 months in the field. This species has been widely used as firewood for energy source particularly by small industries and villagers.
Harvesting Calliandra for energy wood would only require branches or coppices after being cut at particular level in order to secure the main stem to continuously coppicing annually up to 15-20 years (Hendrati, 2015a; Hendrati \& Nurrohmah, 2016).

Through genetic improvement, tree growth can be enhanced optimally beside improving the wood-energy quality, and consequently obtaining a higher and better quality biomass compared to the unimproved ones. It is therefore genetically improved Calliandra is promising to produce individuals for maximizing climate change mitigation. This is because of its abilities like several other plants in capturing carbon due to its very fast growing, reducing the use of fossil fuel since it performs as carbon neutral renewable energy for substitution, sustaining land cover due to harvesting only from the branches and coppices but maintaining the main trees to keep growing, ameliorating soil from its ability to fix nitrogen from the atmosphere, producing green manure from its easily degraded leaves and also helping farmers in providing fodder for cattle (Mugwe, Mgendi, Kungu \& Muna, 2009; Rowe, Hanley, Goulson, Clarke, Doncaster \& Taylor, 2011; Tock, Lai, Lee, Tan \& Bhatia, 2010; Zhang, Wang,Wang \& Quan, 2009).

This paper discusses about genetic improvement resulting from Calliandra 
breeding program. Gain on growth in the nursery is assessed by comparing performances of genetically improved individuals with the unimproved ones. More complete materials are currently grown in the field as materials for assessment the realized gain for growth and quality in the field.

\section{MATERIALS AND METHODS}

\section{A. Materials}

Experiment was carried out in the nursery belongs to the Centre for Forest Biotechnology and Tree Improvement Research and Development Yogyakarta, since September 2015. Improved seeds were collected from genetically improved individuals from Seedling Seed Orchard converted from the progeny test, in Wonogiri Central Java in July 2015.

Improved seeds were collected from improved individuals that had been selected from the progeny test which was established in 2012, in Wonogiri Central Java. They are family number 16, 22, 29, 56 and 58 . Unimproved seeds were the seeds collected during the breeding program (2011-2014) from throughout Indonesia but not included in the progeny test. Those 5 unimproved individuals consist of family number 365,372 , 374, 376 and 375 which were prepared as control. All seeds were germinated in October 2015. Seeds were treated by soaking in hot water $\left( \pm 90^{\circ} \mathrm{C}\right)$ overnight. The next day, the swollen seeds were spread evenly into sterile sands in the containers and cover them with sprinkle of sands over their top before leaving them to germinate. Transplanting of germinated seeds was carried out after 1-2 weeks when the first leaves emerged, by inserting them into polybag $10 \mathrm{~cm} \times 15 \mathrm{~cm}$ containing media of topsoil: compost $=3: 1$. Seedlings of C. calothyrsus were raised up to 4 months, the age that is ready for planting in the field. Basic equipment used in this experiment are digital balance, counter, caliper, long ruler, camera, calculator and stationary etc.

\section{B. Research Design}

A number of 125 seedlings from 5 improved individuals $(16,22,29,56$ and 58) were selected randomly from \pm 250 seedlings with similar proportion per family, then bulked and used to represent genetically improved seedlings. Further, a number of 90 seedlings from unimproved 5 families $(365,372,374$, 376 and 375 ) from around 180 seedlings were selected randomly then bulked and used as representative of the unimproved ones.

\section{Observation and Analyses}

Assessments began when seedlings are ready for field planting which is 4 months. Comparison between both group, the improved and unimproved ones, were carried out in term of growth consisting of height, diameter, number of leaf and seedling quality. Results of both groups were compared and tested by 
using $\mathrm{T}$ - test to see the differences. Meanwhile, the gain is calculated as the increase percentage from the improved seedlings against the unimproved dones.

\section{RESULTS AND DISCUSSION}

\section{A. Results}

Comparison of growth characters between the selected genotypes and the unimproved ones, have proven better growth for the improved than the unimproved ones (Table 1). All characters of the improved genotypes are much higher in values than those of the unimproved one and both groups demonstrate high significant differences ( $\mathrm{p}<0.0001$ ).

Table (Table) 1. Comparison of growth characters between seedlings from genetically improved Calliandra and unimproved genotypes (Perbandingan karakter pertumbuhan antara semai tanaman unggul Calliandra dan yang tidak unggul)

\begin{tabular}{lccc}
\hline \multicolumn{1}{c}{ Traits (Perlakuan) } & $\begin{array}{c}\text { Improved } \\
(\text { Unggul }) \\
(\mathrm{n}=125)\end{array}$ & $\begin{array}{c}\text { Unimproved } \\
(\text { Tidak unggul }) \\
(\mathrm{n}=90)\end{array}$ & $\begin{array}{c}\text { Gain } \\
\text { Perolehan }) \\
(\%)\end{array}$ \\
\hline Number of leaf $($ Nomor daun) $* * *$ & 9.5 & 7.7 & 23.4 \\
\hline Height $($ Tinggi $)(\mathrm{cm}) * * *$ & 62.4 & 50.2 & 24.3 \\
\hline Diameter (mm) $* * *$ & 4.8 & 4.5 & 6.7 \\
\hline Seedling Quality $($ Kualitas bibit $) * * *$ & 13.8 & 11.5 & 20 \\
\hline Remarks (Keterangan $): * * *$ significant differences (perbedaan nyata) $(p<0.0001)$
\end{tabular}

Number of leaves of the seedlings have increased up to 23.4 percent, while the height has been better up to 24.3 percent. Diameter, a character which has a much narrow range in seedlings than height, indicated less percentage of improvement which is 6.7 percent. At the nursery level, the results show that the improved seedlings show seedling quality value of 20 percent higher than the unimproved ones. Visual differences in performances of seedlings representing each of the two groups can be observed clearly in Figure 1.

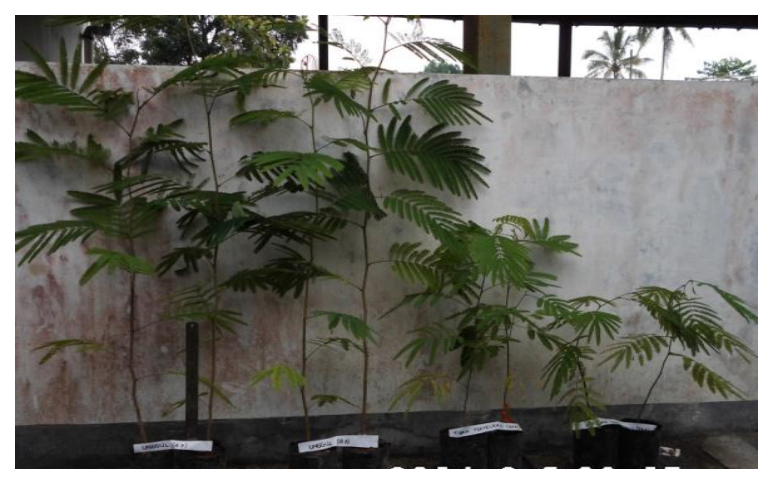

Figure (Gambar) 1. Performances of Calliandra calothyrsus seedlings representing improved (4 on the left) and unimproved genotypes (4 on the right) (Penampilan semai Calliandra calothyrsus yang mewakili tanaman unggul (4 sebelah kiri) dan genotip yang tidak unggul (4 sebelah kanan)) 


\section{B. Discussion}

Individuals of the improved genotypes used in this study were individuals that had been selected based on volume and best diameter of the main stem to approach wood quality (Hendrati, 2015b). Therefore, we expect that the genetically improved individuals would have better growth than those that are not selected. Improvement for higher volume is considered to be more advantageous for fast growing woody species that is meant for energy, because increasing higher biomass for larger plant will save the processing cost (Dermibas, 2011). Hence, genetic improvement is aimed to fulfill this necessity. Better performances of the improved genotypes verify the beneficial improvement and appropriate achievement obtained from the effects of selections during the breeding process. Therefore breeding efforts carried out for this species is worth to be undertaken.

The growth increment gained from tree improvement program of Calliandra assessed at 4 months seedling, has demonstrated encouraging results. This assessment carried out in this nursery is expected to reveal maximum genetic effect and minimum bias due to the uniform environment at nursery environment. Each character has shown different percentages of upgrading after 4 years of breeding process by applying 3 series of selections based on best volume and bigger diameter of the main stem (Hendrati, 2015b). Number of leaves and height are two characters that developed progressively in plants during the seedling stage (Pallardy, 2008), so both traits will be projected to greatly influence its consecutive growth up to the adult stage. Proliferation number of leaves will surely enhanced a much more effective photosynthesis rate than the unimproved ones (Terashima, Fujita, Inoue, Chow \& Oguchi, 2009),

Meanwhile, higher diameter is expected to affect higher wood biomass quality for energy. This refers to study on Calliandra which was analyzed during its breeding process, in which its diameter have positive relationships with its wood quality which is the lignin content ( $r=$ $0.4, \mathrm{p}<0.05)$ and even more with its calorific value $(\mathrm{r}=0.62, \mathrm{p}<0.01) \quad$ (Hendrati, 2015a). Lignin is important for energy wood especially when it will be processed for wood pellet, direct firing and co-firing (Hinchee, Rottmann, Mullinax \& Nehra, 2009), while calorific value is essential character indicating heat energy content. Higher diameter resulted from genetic improvement is expected to be expressed at more mature age. Together with height, diameter would form a much better individuals with higher volume in biomass.

According to SNI 1999 standard (Danu, Rohadi, D \& Nurhasybi, 2006), an increment of seedling quality values that occurred from 11.5 to 13.8 means reduction from first class 
into the second class. This is due to much proportion of seedling height compared to its diameter. While for this species, the advantage obtained from its genetic improvement is that it will be shorter in time to get similar size of seedling in the nursery ready for field plantation (about $30-40 \mathrm{~cm}$ in height and $>4 \mathrm{~mm}$ in diameter). This will save the period of around 1-1.5 months, so saving the cost, if using genetically improved genotypes.

Selection carried out in this breeding process has proven to provide advantages with better individuals in growth. However, this needs to be tested further in the field where edaphic variations and interactions with environment would likely to occur. Therefore, like any conventional breeding work, field plantations need to be established by using similar but more complete genotypes to reveal the realized gains. This will make evaluations possible, not only in growth but also in woodenergy quality.

High genetic gain achieved here, most likely is generated by variations among Calliandra populations collected from throughout Indonesia which was revealed in the progeny test (Nurtjahjaningsih, Sulistyawati \& Rimbawanto, 2016). This variation which caused high heritability values (Hendrati, 2015a) might be influenced by different growth habitat on its original population including elevation (Hendrati, 2013).

Take note that, Calliandra was introduced to Indonesia in 1930 (Nurtjahjaningsih et al., 2016), since then, this species found scattered all around Indonesia might have been able to produce more than 20 generations at particular locations. Due to the ability to adapt to the local condition, these populations might form land races with different genetic structures. Good land race performers can be generated from the natural process of selection surviving those that developing mechanism of adaptation (Elridge, Davidson, Harwood, \& Van Wyk, 1993). These type of origins when included as genetic materials in the breeding program might perform better than the others.

\section{CONCLUSIONS}

From this study, Calliandra calothyrsus breeding carried out for four years has produced much better seedling growth from selected individuals as compared to those unimproved ones. Further studies using a more complete material currently grown in the field will be used for assessing the true gain in growth and quality. This is expected to be in accordance with the seedling performance in the nursery observed in this study.

\section{ACKNOWLEDGEMENT}

Appreciation is addressed to Directors and staffs of Centre for Forest Biotechnology and 
Tree Improvement Research and Development that provide infra structures, funding and facilitate this research project. My sincere and deep thanks are also expressed to all of my team members for their help, patience and kindness to fulfil and finish all the jobs required to undertake this research. I am also deeply grateful to Prof. Dr Budi Leksono for his meaningful advices.

\section{REFERENCES}

Danu, Rohadi, D., \& Nurhasybi. (2006). Teknologi dan standardisasi benih dan bibit dalam rangka menunjang keberhasilan GERHAN. In M. Haryono (Ed.), Optimalisasi Peran Iptek dalam Mendukung Peningkatan Produktivitas Hutan dan Lahan. Prosiding Seminar Hasilhasil Penelitian; Jambi, 22 Des 2005 (pp. 6970). Bogor: Badan Penelitian dan Pengembangan Kehutanan, Pusat Penelitian dan Pengembangan Hutan dan Konservasi Alam.

Dermibas, A. (2011). Competitive liquid biofuels from biomass. Applied Energy, 88(1), 17-28. https://doi.org/10.1016/j.apenergy.2010.07.01 6

Dwiyedi, Edi, P., \& Khanna, M. (2014). Woodbased bioenergy products - land or energy efficient? Canadian Journal of Forest Research. Canadian Journal of Forest Research, 44, 1187-1195. https://doi.org/dx.doi.org/10.1139/cjfr-20140210

Elridge, K., Davidson, J., Harwood, C., \& Van Wyk, G. (1993). Eucalyptus Domestication and Breeding. Oxford: Clarendon Press.

Hendrati, R. L. (2013). Hubungan tinggi bebas cabang Kaliandra (Caliandra callothyrsus)dengan ketinggian tempat tumbuh di Indonesi. Wanabenih, 14(1, Juli 2013).

Hendrati, R. L. (2015a). Genetic Improvement of Calliandra calothyrsusfor Qualified Wood Energy. In 3rd INAFOR: Forestry research to support sustainable timber production and self-sufficiency in food, energy, and water (pp. 535-543). Bogor 21-22 Oktober 2015. Bogor: Ministry of Environtment and Forestry, Research, Development and Innovation Agency.

Hendrati, R. L. (2015b). Sustainable Plantation and Environment Protection with Genetically Improved Calliandra to Fulfil Market and Socio Economic Demands. In Proceeding International Seminar on Challenges of Sustainable Forest Plantation Development, Yogyakarta. Indonesia. 26th Nopember 2015 (pp. 125-135). Centre for Forest Biotechnology and Tree Improvement.

Hendrati, R.L. \& Nurrohmah, S. H. (2016). Penggunaan Rhizobium dan Mikhorhiza untuk Pertumbuhan Calliandra callothyrsus Unggul. Jurnal Pemuliaan Tanaman Hutan Vol. 10 No.2. Desember 2016. pp 71-81. http://ejournal.forda-mof.org/ejournallitbang/index.php/JPTH/article/view/2392

Hinchee, M., Rottmann, W., Mullinax, L., \& Nehra, N. (2009). Short-rotation woody crops for bioenergy and biofuels applications. In Vitro Cellular \& Developmental Biology Plant., 45(6), 619-629. https://doi.org/10.1007/s11627-009-9235-5

Mugwe, J., Mgendi, D., Kungu, J., \& Muna, M. . (2009). Maize Yields Response to Application of Organic and Inorganic Input under Onstation and On-farm Experiments in Central K. Experimental Agriculture, $45(1$ January 2009), 47-59.

Murtala, A. M., Aliyu, B. A., \& Babagana, G. (2012). Biomass Resource as a Source of Sustainable Energy Production in Developing Countries. Journal of Applied Phytotechnology in Environmental Sanitation, $1((2)), 103-112$.

Nurtjahjaningsih, I.L.G. Sulistyawati, P., \& Rimbawanto, A. (2016). Struktur Genetik Calliandra callothyrsus di Indonesia Menggunakan Penanda Random Amplified Polymorphism DNA (RAPD). Jurnal Pemuliaan Tanaman Hutan, 10(1 Juni 2016), 31-38.

Oliver, C. D., Nassar, N. ., Lippke, B. ., \& McCarter, J. . (2014). Carbon, Fossil Fuel, and Biodiversity Mitigation With Wood and 
Forests. Journal of Sustainable Forestry, 33, 248-275.

https://doi.org/10.1080/10549811.2013.83938 6

Openshaw, K. (2010). Guest Editorial: Renewable Energy and Developmen. Journal of Tropical Forest Science, 22(1), 5-6.

Pallardy, S. G. (2008). Physiology of Woody Plants. Burlington. USA: Academic Press.

Rowe, R. L., Hanley, M. E., Goulson, D., Clarke, D. J., Doncaster, C. ., \& Taylor, G. (2011). Potential benefits of commercial willow Short Rotation Coppice (SRC) for farm-scale plant and invertebrate communities in the agrienvironment. Biomass and Bioenergy, 35(1 january 2011), 325-336. https://doi.org/10.1016/j.biombioe.2010.08.04 6

Terashima, I., Fujita, T., Inoue, T., Chow, W. S., \& Oguchi, R. (2009). Green Light Drives Leaf Photosynthesis More Efficiently than Red
Light in Strong White Light: Revisiting the Enigmatic Question of Why Leaves are Green. Plant and Cell Physiology, 50(14, 1 April 2009), 684-697. https://doi.org/10.1093/pcp/pcp034

Tock, J., Lai, C., Lee, K., Tan, K., \& Bhatia, S. (2010). Banana biomass as potential renewable energy resource: A Malaysian case study. Renewable and Sustainable Energy Reviews, 14(2, Februari 2010), 798-805.

Zalesny, R. S., Hall, R., Zalesny, J., McMahon, B., Berguson, W., \& Stanosz, G. (2009). Biomass and Genotype $\times$ Environment Interactions of Populus Energy Crops in the Midwestern United States. Bio Energy Research, 2(3), 106-122.

Zhang, Q., Wang, Wang, X., \& Quan X. (2009). Carbon concentration variability of 10 Chinese temperate tree species. Forest Ecology and Management, 258(5, 20 agustus 2009), 722-727. 